\title{
Descriptive Study on E-Teaching Implementation of Learning Process at Kupang State of Polytechnic
}

\author{
Rosdiana Mata*, Puteri Ayu Pratiwi, Yosef Paseli Dheghu \\ Accounting Department \\ Kupang State of Polytechnic \\ Kupang, Indonesia \\ *ody.smart@gmail.com, puteriayu.pratiwi@gmail.com, pdheghu@gmail.com
}

\begin{abstract}
This study aimed to analyse the strength, weaknesses, opportunities, and threats of e-teaching implementation at the Kupang State of Polytechnic during even semester 2019/2020. This study also will examine the e-teaching implementation strategy in the future. The study was conducted using questionnaires. The data obtained from 45 respondents by using a simple random sampling technique. Descriptive qualitative methods and SWOT analyses were used to formulate the strategy of e-teaching implementation at the Kupang State of Polytechnic. The results show that the strength in internal factors is greater than the weaknesses. For the external factor, the opportunity is more significant than threats. Thus, the strategy of strength-opportunity (SO) should be applied in e-teaching implementation covering improvement the quality of lecturer competencies in teaching and mastery of e-teaching technology; second, increasing collaboration among institutions, lecturers, and internet providers; third creating new e-teaching and elearning technologies to be used at the Kupang State of Polytechnic.
\end{abstract}

Keywords-higher education, e-teaching, e-learning, SWOT analyses, teaching strategy

\section{INTRODUCTION}

Web-based teaching and learning are prevalent nowadays. Due to the COVID-19 outbreak in Indonesia, Kupang State of Polytechnic suddenly has to change traditional teaching into eteaching. Actually, in 2003, Indonesia applied online learning and teaching for higher education. Some universities are developing their e-learning platform, but the others use the open-source platform such as Moddle. in higher education, Eteaching itself is a precondition of the e-learning process [1]. Development of information and communication technology, the atmosphere of teaching and learning in higher education has transformed into web-based learning and teaching. Eteaching is defined as teaching and learning processes that involve educators and students together in different places by using the internet [2]. Thus, the learning and teaching process can occur anywhere, using an internet connection as a vital tool. An online instructor can also be called an online instructor. Denies [3] defined an online educator in an online course as one "who interacts directly with learners to support their learning process when they are separated from the tutor in time and place for some or all of these direct interactions." It breaks the conventional way of teaching from face-to-face meetings in a classroom into online teaching. While the purpose of using e-learning in a learning system is to open broad access to education to society and improve the quality of learning [4]. Thus, space and time were not a matter of doing online learning and teaching nowadays.

In early of 2020, schools and colleges were closed as the impact of the COVID-19 outbreak. Distance learning and teaching issues become a prevalent issue then. Social distancing suggested by the Indonesia government to avoid COVID-19 spread out. There is only one way to do the policy of study and work from home online learning. It has become a vital alternative to keep maintaining the education process. Lecturers and students were forced to be familiar and able to use educational technology from a different platform such as Zoom, Google Classroom, WA, Edmodo, telegram, et al. Those educational technologies can help bridge the distance between the learners and their learning environment [5].

The availability of educational technology has helped many instructors and students in the E-learning process. As instructors who did online teaching, they are expected to have qualified competence in teaching techniques and master the teaching technology itself. Changes in the online teaching process's role also impact the competencies that must be possessed. Thus as a lecturer they need to apply seven practical teaching principles in their virtual class, those are: (1) encourage student-faculty contact; (2) encourage cooperation among students; (3) Encourage active learning; (4) give prompt feedback; (5) emphasize time on task; (6) communicate high expectations, (7) respect diverse talents and ways of learning, [3].

E-learning application before COVID-19 functions as a supplement and complement, but it has been used as a substitute or substitution now [6]. This phenomenon is known as a new trend in education, significantly higher education, which will become a significant revolution in education. Online teaching by a lecturer or instructor does not merely change the teaching model from face to face directly online, 
but also the function and role also change. Teaching roles shifting in higher education has been changed into three fundamentals changing: cognitive, affective, and managerial [3].

The use of educational technologies makes it easier for lecturers and students to be more flexible in managing learning activities. Besides, e-learning is considered capable of changing the paradigm of transmission of knowledge modes to coaching and mentoring modes. Faculty role shifts to more coaching, guiding and mentoring than being a speaker alone who transferring knowledge to the students as happened in the traditional classroom [7,8]. This will lead to increased effectiveness and flexibility in the teaching and learning process [9].

Institutions, lecturers, and learners may get benefits from doing distance learning and teaching. Teachers do not have to be present and face to face with students. Teachers can be present virtually to teach and assign assignments to students and provide online assessments [10]. E-learning is very effective in the learning process because it saves both teachers and students time and money. The availability of teaching materials, a more interactive discussion, the ease of giving and completing study assignments and implementing examinations are also the advantages of implementing e-learning and teaching [9].

Adapting e-learning without any planning will bring failure in the process and ends with cost overruns because it needs innovation, e-learning strategies, development time, money, technological infrastructure, and leadership [11]. More than that, e-learning and teaching implemented in an unprepared educational institution will only face many obstacles. Those barriers are dispositional, learning style, instructional, organizational, situational, content-suitability, and technological [12]. A case study in Uganda shows that distance education for higher education faces five significant challenges: infrastructure, the cost, the relevance of the curriculum, inadequate expertise in distance education, and poor attitudes towards distance learning [5]. Consequently, this research will try to determine internal and external factor analysis summary (strengths, weaknesses, opportunities, and threats) of e-teaching implementation for lecturers and institutions to determine the future of e-teaching strategies. The research questions of the study have been formulated as:

- What are the strengths and weaknesses of e-teaching implementation at the Kupang State of Polytechnic in online teaching?

- What are the opportunities and threats of e-teaching implementation at the Kupang State of Polytechnic in online teaching?

- How to determine the e-teaching implementation strategy at the Kupang state of Polytechnic in the future?

\section{METHODS}

This study uses a qualitative descriptive analysis method. This study's population were all lecturers taught at the Kupang State Polytechnic as many as 206 people. The sampling technique used was a simple random sampling technique. The number of samples taken as respondents was 67 people with error tolerance 0.10 . This calculation is following the Slovin formula [13].

This study's data collection technique was carried out by conducting literature and documentation studies, namely research journals on e-learning and e-teaching, lecturer data, and lecturer teaching decision letters. It is determining the number of lecturers and analysing the internal factors of human resources in implementing e-teaching. Furthermore, researchers interviewed with the head of internal quality assurance at the Kupang State Polytechnic and lecturers who teach online to obtain policy data and applied online teaching strategies. The data is then analysed and generated into 20 variable indicators from internal factors and external factors. Internal factors include strength and weakness, while opportunity and threats are external factors. Data is also collecting from questionnaires distributed via Google Form as the main instrument in rating and weighting each indicator item for analysis. This questionnaire was designed by the researchers themselves using indicators in the analysis of internal and external factors. The questionnaire was designed using 29 closed statements. The scale value used in calculating the indicators' weighting is the Likert scale 1-5, namely, strongly disagree, disagree, doubt, agree, and strongly agree. Meanwhile, the rating calculation uses a 1-4 Likert scale, which is very weak, weak, strong, and very strong.

The research instrument used a questionnaire with one shoot technique. The validity and reliability of this instrument used SPSS statistics 16. Twenty-nine statements were declared valid after the validity test was carried out with $5 \%$ significance, obtained $\mathrm{r}$ count was more remarkable than $\mathrm{r}$ table. The alpha coefficient value standard is 0.6 , so that this research instrument is declared reliable.

This study uses a SWOT analysis technique (Strengths, weaknesses, opportunities, threats). SWOT Analysis is an instrument used by companies for strategic planning and strategic management [14]. The SWOT analysis technique is to compare external factors and internal factors [15]. A SWOT analysis requires External Strategic Factors (EFAS) and Internal Strategic Factors (IFAS) matrices. The following are the stages of determining External Strategy Factors and Internal Strategic Factors:

- List them in column 1 (5 to 10 opportunities and threats). Weight each factor ranging from 1.0 (very important) to 0.0 (not important) or on a scale of 1 to 5 $(1=$ not important, $5=$ very important $)$.

- Next, adding the weights (in column 2) of strengths, weaknesses, opportunities, and threats. Then, calculated the relative weight/item weight for each indicator in the 
strengths and weaknesses so that the total weight value becomes 1 or $100 \%$. Likewise, the calculation of opportunity and threat indicators.

- Determine the rating (in column 3) by giving a value of 4 (outstanding) to 1 (low), giving rating value to positive variables (all variables that fall into the strength and opportunity category). Giving rating values to negative variables (weaknesses and threats) is the opposite.

- The score (in column 4) is obtained based on the weight value multiplied by the rating value. The internal factor's total score shows that the closer the score is to 1 , the more internal weaknesses are compared to the strengths. Meanwhile, the more the value is closer to 4 , the more strengths it has compared to the weaknesses. Likewise, with the total score for external factors, The more the total score approaches 1 , the more threat it is to the opportunity. Meanwhile, if the total score is close to 4 , there are more opportunities than threats. Then, arrange them in column 1 (5 to 10 opportunities and threats, as illustrated in Table 1

\section{TABLE I. SWOT MATRIX [15]}

\begin{tabular}{|l|l|l|}
\hline & $\begin{array}{l}\text { Strengths (S) } \\
\text { Stated 5-10 internal } \\
\text { weakness factors }\end{array}$ & $\begin{array}{l}\text { Weakness (W) } \\
\text { Stated 5-10 internal } \\
\text { strength factors }\end{array}$ \\
\hline $\begin{array}{l}\text { Opportunities (O) } \\
\text { Sstated 5-10 } \\
\text { external } \\
\text { opportunities } \\
\text { factors }\end{array}$ & $\begin{array}{l}\text { Strategi SO } \\
\text { Create strategies that } \\
\text { use strength to take } \\
\text { advantage of } \\
\text { opportunities }\end{array}$ & $\begin{array}{l}\text { Strategi WO } \\
\text { Create strategies } \\
\text { that minimize } \\
\text { weaknesses to take } \\
\text { advantage of } \\
\text { opportunities }\end{array}$ \\
\hline $\begin{array}{l}\text { Threats (T) } \\
\text { Stated 5-10 } \\
\text { external threats } \\
\text { factors }\end{array}$ & $\begin{array}{l}\text { Strategi ST } \\
\text { Create strategies that } \\
\text { use strength to } \\
\text { overcome threats. }\end{array}$ & $\begin{array}{l}\text { Strategi WT } \\
\text { Create strategies } \\
\text { that minimize } \\
\text { weaknesses and } \\
\text { avoid threats. }\end{array}$ \\
\hline
\end{tabular}

\section{RESULTS}

\section{A. Validity and Reliability}

SWOT questionnaire instrument was administered to 67 lecturers, 45 lecturers (response rate 67\%) complete. Twentynine statements were declared valid after the validity test was carried out with $r$ table $(0.301)$ with $5 \%$ significance, obtained $r$ count was greater than $r$ table. The alpha coefficient value 0.657 , so this research instrument is declared reliable.

The sample is about $67 \%$ of the total standard sample; thus, it cannot be claimed that this study's participant represents all samples on the population at the Kupang State of Polytechnic. Nevertheless, the study revealed some data about e-teaching implementation vital indicators such as education level, teaching experience, teaching skills, ability to use various technologies learning, and experience following e-learning training. Most of the respondents (93\%) were lecturers with master education status. $60 \%$ of those who already have a lecturer certificate, and $95 \%$ have attended teaching training. Besides, $51 \%$ of them have attended e-learning training. $100 \%$ of respondents are proficient in using laptops in teaching. The use of online learning application technology is dominated by zoom (77\%) - all respondents use 2-3 learning technology applications in their e-teaching classes as a combination, such as google classroom, WhatsApp, Edmodo, CloudX, Email, YouTube, Facebook and Telegram.

\section{B. Internal FactorAnalysis Summary (IFAS) of E-teaching implementation}

The table below is the results from the internal analysis of the Kupang state polytechnic by looking at human resources, cooperation, and the ability to use learning technology as internal data obtained from questionnaires that have been distributed. Then it can be calculated the value of weight, rating, and score of their effect on the implementation of eteaching by looking at the Table 2 :

TABLE II. IFAS (INTERNAL FACTOR ANALYSIS SUMMARY)

\begin{tabular}{|c|l|c|c|c|c|}
\hline No. & \multicolumn{1}{|c|}{ Strength } & Weight & $\begin{array}{c}\text { Weight } \\
\text { Item }\end{array}$ & Rating & Score \\
\hline 1. & $\begin{array}{l}\text { Lecturers already have expertise } \\
\text { in the field of teaching }\end{array}$ & 4.46 & 0.113 & 3 & 0.393 \\
\hline 2. & $\begin{array}{l}\text { Institutional support and } \\
\text { collaboration were right in the } \\
\text { implementation of online } \\
\text { teaching }\end{array}$ & 3.97 & 0.101 & 3 & 0.303 \\
\hline 3. & $\begin{array}{l}\text { Lecturers already have an } \\
\text { excellent pedagogical ability }\end{array}$ & 4.11 & 0.104 & 3 & 0.312 \\
\hline 4. & $\begin{array}{l}\text { Good mastery of online learning } \\
\text { technology }\end{array}$ & 4.21 & 0.107 & 3 & 0.321 \\
\hline 5. & $\begin{array}{l}\text { Lecturers motivation in carrying } \\
\text { out their duties }\end{array}$ & 4.06 & 0.103 & 4 & 0.412 \\
\hline & Total Weakness & 20.81 & 0.528 & & 1.741 \\
\hline No. & \multicolumn{1}{|c|}{ Weight } & $\begin{array}{c}\text { Weight } \\
\text { Item }\end{array}$ & Rating & Score \\
\hline 1. & $\begin{array}{l}\text { The slow feedback and } \\
\text { interaction between lecturers and } \\
\text { students, especially in practical } \\
\text { subjects }\end{array}$ & 2 & 0.061 & 3 & 0.306 \\
\hline 2. & $\begin{array}{l}\text { Unowned and academic support } \\
\text { system for online teaching and } \\
\text { learning (e-learning program) }\end{array}$ & 2.06 & 0.063 & 3 & 0.297 \\
\hline 3. & $\begin{array}{l}\text { The ability to make an interactive } \\
\text { teaching material that is less/not } \\
\text { optimal (multimedia-based } \\
\text { content) }\end{array}$ & 2.53 & 0.078 & 4 & 0.352 \\
\hline 4. & $\begin{array}{l}\text { Wifi-LAN network availability } \\
\text { that is not optimal yet }\end{array}$ & 2.91 & 0.089 & 3 & 0.234 \\
\hline 5. & $\begin{array}{l}\text { The low participation and } \\
\text { enthusiasm of students in online } \\
\text { teaching }\end{array}$ & 2.06 & 0.063 & 4 & 0.4 \\
\hline & Total & 11.56 & 0.354 & & 1.203 \\
\hline
\end{tabular}

The internal factor data is obtained from the sum of scores for each indicator of strengths and weaknesses in all respondents, divided by the total number of respondents, amounting to 45 . The average weight value on the strength factor is 4.16, which means that each respondent gives a value of agreeing to agree strongly. For the weakness factor, the 
average weight value is 2.31, which means that each respondent gives an agreed value. The result indicates that the implementation of e-teaching at the Kupang State Polytechnic is the most vital point in utilizing internal strengths to overcome weaknesses.

\section{External Factor Analysis Summary (EFAS) of E-teaching implementation}

Based on the results of the analysis of external factors, the effects of opportunities and threats on the application of eteaching at Kupang State Polytechnic can be calculated as follows Table 3:

TABLE III. EFAS (EXTERNAL FACTOR ANALYSIS SUMMARY)

\begin{tabular}{|c|c|c|c|c|c|}
\hline No. & Opportunity & Weight & $\begin{array}{l}\text { Weight } \\
\text { Item }\end{array}$ & Rating & Score \\
\hline 1. & $\begin{array}{l}\text { Creating e-learning programs that } \\
\text { are in accordance with the } \\
\text { vocational curriculum }\end{array}$ & 4.06 & 0.101 & 3 & 0.303 \\
\hline 2. & $\begin{array}{l}\text { Improving student analysis } \\
\text { capacity and ability to enrich/get } \\
\text { more learning resources }\end{array}$ & 3.55 & 0.089 & 3 & 0.267 \\
\hline 3. & $\begin{array}{l}\text { Increasing the ability of lecturers } \\
\text { in making interactive e-teaching } \\
\text { materials }\end{array}$ & 4.2 & 0.105 & 3 & 0.315 \\
\hline 4. & $\begin{array}{l}\text { Effectiveness and time efficiency } \\
\text { in teaching }\end{array}$ & 3.57 & 0.089 & 4 & 0.356 \\
\hline 5. & $\begin{array}{l}\text { Collaboration with private } \\
\text { partners as internet providers to } \\
\text { support online teaching }\end{array}$ & 4.13 & 0.103 & 3 & 0.309 \\
\hline & Total & 19.51 & 0.487 & & 1.55 \\
\hline No. & Threats & Weight & $\begin{array}{l}\text { Weight } \\
\text { Item }\end{array}$ & Rating & Score \\
\hline 1. & $\begin{array}{l}\text { Online teaching funding is } \\
\text { expensive }\end{array}$ & 1.88 & 0.064 & 3 & 0.192 \\
\hline 2. & $\begin{array}{l}\text { Ownership of online learning } \\
\text { facilities and infrastructure for } \\
\text { students }\end{array}$ & 2.15 & 0.073 & 3 & 0.219 \\
\hline 3. & $\begin{array}{l}\text { Availability of time and internet } \\
\text { to interact with students }\end{array}$ & 2.15 & 0.073 & 3 & 0.219 \\
\hline 4. & $\begin{array}{l}\text { Teaching and learning resources } \\
\text { were not up-to-date according to } \\
\text { the curriculum changes. }\end{array}$ & 1.55 & 0.053 & 3 & 0.159 \\
\hline 5. & $\begin{array}{l}\text { The low economic ability of } \\
\text { students }\end{array}$ & 1.91 & 0.065 & 4 & 0.26 \\
\hline & Total & 9.64 & 0.328 & & 1.049 \\
\hline
\end{tabular}

External data of the above factors were obtained from the sum of the scores for each indicator of opportunities and threats to all respondents, divided by the total number of respondents, which amounted to 45. The average weighted value of the opportunity factor was 3.90 , which means that each respondent gave a neutral value to agree. Whereas for the threat factor, the average weight value is 1.92, which means that each respondent gives a value that strongly agrees to agree. The result indicates that the implementation of e-teaching at the Kupang State Polytechnic has a tremendous opportunity. The opportunity can be used to carry out a strategy to overcome threats that are also at a reasonably large point.

\section{SWOT Analysis Diagram}

Furthermore, the total score for each of the internal and internal factors is strength (4.162), weakness (2.312), opportunity (3.902), and threats (1.928). It can be seen that $\mathrm{X}$ is the difference in the total score of strength and weakness is 1.85 , while $\mathrm{Y}$ is the difference between opportunities and threats is 1.974. Thus, the implementation of e-teaching at the Kupang State Polytechnic is in quadrant 1 based on the SWOT analysis diagram. The position in quadrant 1 is a very favourable situation. Kupang State Polytechnic as an educational institution, and its lecturers have opportunities and strengths to take advantage of current opportunities. The strategy that must be applied in this condition is to support a growth-oriented strategy. The result can be seen in Figure 1.

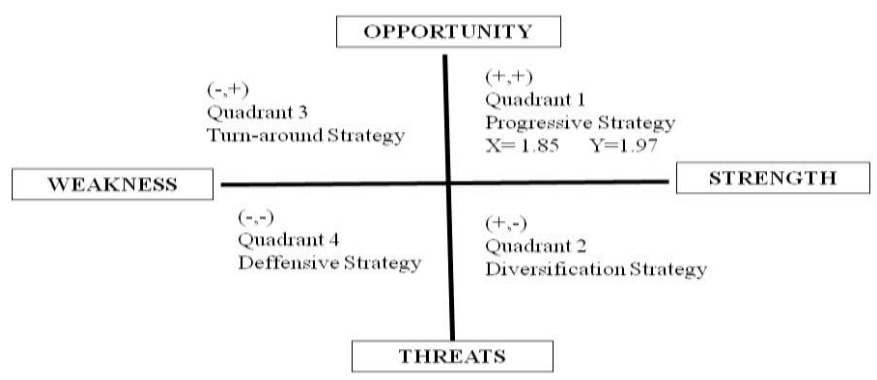

Fig. 1. SWOT analysis diagram

\section{E. SWOT Matrix}

The SWOT Matrix below clearly describes how the external opportunities and threats are owned and the internal strengths and weaknesses. This matrix produces four alternative strategy cells, which can be seen in the Table 4: 
TABLE IV. SWOT MATRIX KUPANG STATE OF POLYTECHNIC

\begin{tabular}{|c|c|c|}
\hline & $\begin{array}{l}\text { Strengths (S) } \\
\end{array}$ & Weakness $(\mathrm{W})$ \\
\hline EFAS & $\begin{array}{l}\text { - Lecturers already have expertise in the field of } \\
\text { teaching } \\
\text { - Institutional support and collaboration were } \\
\text { good in online implementation of online } \\
\text { teaching } \\
\text { - Lecturers already have an excellent } \\
\text { pedagogical ability } \\
\text { - Good mastery of online learning technology } \\
\text { - Lecturers motivation in carrying out their } \\
\text { duties }\end{array}$ & $\begin{array}{l}\text { - The slow feedback and interaction between } \\
\text { lecturers and students, especially in practical } \\
\text { subjects } \\
\text { - Unowned and academic support system for } \\
\text { online teaching and learning (e-learning } \\
\text { program) } \\
\text { - The ability to make an interactive teaching } \\
\text { material that is less/not optimal (multimedia- } \\
\text { based content) } \\
\text { - Wi-Fi-LAN network availability that is not } \\
\text { optimal yet } \\
\text { - The low participation and enthusiasm of } \\
\text { students in online teaching }\end{array}$ \\
\hline Opportunities (O) & \begin{tabular}{|c|} 
Strategi SO \\
\end{tabular} & $\begin{array}{r}\text { Strategi WO } \\
\end{array}$ \\
\hline $\begin{array}{l}\text { - Creating e-learning programs that are } \\
\text { following the vocational curriculum } \\
\text { - Improving student analysis capacity and } \\
\text { ability to enrich/get more learning resources } \\
\text { - Increasing the ability of lecturers in making } \\
\text { interactive e-teaching materials } \\
\text { - Effectiveness and time efficiency in teaching } \\
\text { - Collaboration with private partners as internet } \\
\text { providers to support online teaching }\end{array}$ & $\begin{array}{l}\text { - Improve the quality of lecturer competencies } \\
\text { in teaching and mastery of e-teaching } \\
\text { technology. } \\
\text { - Increasing collaboration between institutions, } \\
\text { lecturers, and internet supervisors as the } \\
\text { primary foundation for student success in } \\
\text { online teaching } \\
\text { - Encouraging lecturer synergy in creating new } \\
\text { teaching and learning technologies }\end{array}$ & $\begin{array}{l}\text { - Socializing the benefits of online teaching } \\
\text { technology as an alternative means of } \\
\text { teaching and learning interaction that is } \\
\text { integrated and under current conditions } \\
\text { (Technology Literacy) } \\
\text { - Improve the quality of online teaching } \\
\text { material and packaging from lecturers to be } \\
\text { more attractive to students. } \\
\text { - Increase commitment of institutional supports } \\
\text { and internet provider to facilitate internet } \\
\text { access for lecturers and students }\end{array}$ \\
\hline Threats (T) & Strategi ST & Strategi WT \\
\hline $\begin{array}{l}\text { - Online teaching funding is expensive. } \\
\text { - Ownership of online learning facilities and } \\
\text { infrastructure for students. } \\
\text { - Availability of time and internet to interact } \\
\text { with students } \\
\text { - Teaching and learning resources were not up- } \\
\text { to-date according to the curriculum changes. } \\
\text { - The low economic ability of students }\end{array}$ & $\begin{array}{l}\text { - Adapting the latest teaching methods and } \\
\text { learning resources to be in line with the } \\
\text { current curriculum } \\
\text { - Implement synchronous, asynchronous, and } \\
\text { blended learning systems. }\end{array}$ & $\begin{array}{l}\text { - Establish cooperation with internet providers } \\
\text { and online teaching technology developers for } \\
\text { the provision of online teaching facilities } \\
\text { - Prioritize students who have limited facilities, } \\
\text { infrastructure to access online teaching }\end{array}$ \\
\hline
\end{tabular}

\section{DISCUSSION}

Based on the result of internal factors on the implementation of e-teaching at the Kupang State Polytechnic, as shown in Table II, the strength factor's total score plus the weakness factor is 2,944 . Internal condition is declared good because the strength factor's average value is higher than the weakness factor. The strength factor that significantly influences the implementation of e-teaching is the Lecturers' indicator already having expertise in teaching with a weight of 4.46 or an item weight of 0.113 . In the second and third positions, a good mastery of online learning technology and lecturers already have an excellent pedagogic ability. Meanwhile, on the weakness factor, the highest point that has influence is the Wi-Fi-LAN network availability that is not optimal yet with a weight of 2.91 or an item weight of 0.089 . The other is followed by making an interactive teaching material that is less / not optimal (multimedia-based) and an unowned academic support system for online teaching and learning (e-learning program).
Moreover, the external condition of the implementation of e-teaching at the Kupang State Polytechnic in table III is also in good condition because the opportunity factor is higher than the score on the threat factor. The total score on external factors is 2,599. The highest opportunity value is found in the indicator points of increasing the ability of lecturers to make interactive e-teaching materials, collaborate with private partners as internet providers to support online teaching, and create e-learning programs that are in accordance with the vocational curriculum. The weight values are 4.2, 4.13, and 4.06 , or the item weights are $0.105,0.103$, and 0.101 . Furthermore, the highest threat factor is obtained from 2 indicators with a similar weight, namely 2.15 . The first indicator is the ownership of online learning facilities and infrastructure for students; the second is the availability of time and the internet to interact with students. The next highest threat is the low economic abilities of students.

The SWOT analysis results show that the position of the implementation of e-teaching on the learning process at the Kupang State of Polytechnic is in quadrant 1 with a value of $\mathrm{X}$ $=1.85$ and $\mathrm{Y}=1.974$. The $\mathrm{X}$-axis value is obtained from the 
total average weight of Strength minus the average weakness's total weight. Y value is obtained from the average total weight of opportunity minus the average total weight of threats. Thus, the strategy applied is a growth-oriented strategy where the SWOT matrix is included in the opportunity strategy (SO). It is hoped that this strategy can be applied to the implementation of e-teaching in the learning process at the Kupang State Polytechnic by utilizing the strength of human resources owned by the institution to get higher opportunities.

Things that can be done as a manifestation of the opportunity strategy are improving the quality of lecturer competencies in teaching and mastery of e-teaching technology. This result strategy is also a confirmation from a previous study at Hasnur Polytechnic that human resources variables are superior but require improvements in selfdevelopment, technology, and creativity [16]. Kupang State Polytechnic can organize workshops on e-teaching. This strategy is expected to equip lecturers to be more familiar and proficient in using learning technology and applying it to the class they taught. In addition, to offset the pace of technological development. Second, Increasing collaboration among institutions, lecturers, and internet providers as the primary foundation for an excellent e-teaching implementation. Through good cooperation among them, it may fulfil the needs of lecturers and students in the e-teaching implementation process. Third, encouraging the lecturer to be synergized in creating new teaching technologies. Owning new-teaching and e-learning technology that can be used en masse at the campus can help lecturers become more proficient at mastering technology. Institutionally, it can also control the implementation of e-teaching more systematically. Besides, students also do not need to download various learning technology platforms for the benefit of their learning process. Every subject with different platforms needs a different number of quotas. Of course, this will significantly affect the sustainability of e-teaching.

Recent studies approved that $97 \%$ of students commented that e-learning provides benefits. E-learning lets students learn content individually and can improve their learning incentive. The lecturers' benefit is that it is more effective in analysing the learning process and pupils in order to improve the professional performance of lecturers [17]

\section{CONCLUSION}

The implementation of e-teaching that has been taking place at the Kupang State Polytechnic is still something new to be implemented. This policy is applied as a form of prevention of Covid-19 transmission. The e-teaching implementation still has many shortcomings and weaknesses in various aspects. However, the analysis shows that the strength and opportunity are very high. Therefore, it takes commitment from the institution and lecturers to develop existing resources so that they can implement better e-teaching in the future. This can be done through 3 strategy opportunities: first, improve the quality of lecturer competencies in teaching and mastery of e-teaching technology; second, increasing collaboration among institutions, lecturers, and internet providers; third, creating new e-teaching and e-learning technologies.

\section{ACKNOWLEDGMENT}

This study was supported by DIPA funding from the Kupang State of Polytechnic. We gratefully thank you for the financial support. We thank Nonce F. Tuati as the director of Kupang State of Polytechnic.

\section{REFERENCES}

[1] S. Guri-Rosenbilt, "E-Teaching in Higher Education: An Essential Prerequisite for E-Learning," Journal of New Approaches in Educational Research, vol. 7, no. 2, pp. 93-97, 2018.

[2] S. Ko and S. Rossen, Teaching online: A practical guide. 3rd Edition, New York: Routledge, 2010.

[3] C. Ní Shé et al., "Teaching online is different: critical perspectives from the literature," 2019

[4] S. Suharyanto and A.B.L. Mailangkay, "Penerapan E-learning sebagai Alat Bantu Mengajar dalam Dunia Pendidikan,” J. Ilm. Widya, vol. 4 no. 3, 2018.

[5] G.N. Basaza, N.B. Milman, and C.R. Wright, "The challenges of implementing distance education in Uganda: A case study," Int. Rev. Res. Open Distrib. Learn., vol. 11, no. 2, pp. 85-91, 2010.

[6] E. Karwati, "Pengaruh Pembelajaran Elektronik (E-Learning) Terhadap Mutu Belajar Mahasiswa," J. Penelit. Komun., vol. 17, no. 1, pp. 41-54, 2014

[7] J.V Boettcher and R.-M. Conrad, The online teaching survival guide: Simple and practical pedagogical tips. $1^{\text {st }}$ ed. John Wiley \& Sons, 2016.

[8] J.V Boettcher and R.-M. Conrad, The online teaching survival guide: Simple and practical pedagogical tips. $2^{\text {nd }}$ ed. John Wiley \& Sons, 2016.

[9] F. Fandianta, G.Y. Sanjaya, and W. Widyandana, "Fleksibilitas Belajar Mengajar Melalui Metode Blended Learning," J. Pendidik. Kedokt. Indones. Indones. J. Med. Educ., vol. 2, no. 2, pp. 146-153, 2013.

[10] I. Purwandani, “Analisa Tingkat Kesiapan E-Learning (E-Learning Readiness) Studi Kasus: AMIK Bina Sarana Informatika Jakarta,' Bianglala Inform., vol. 5, no. 2, 2017.

[11] C.H. Aydın and D. Tasci, "Measuring readiness for e-learning: Reflections from an emerging country," J. Educ. Technol. Soc., vol. 8 no. 4, pp. 244-257, 2005.

[12] P. Mungania, "Employees' perceptions of barriers in e-Learning: the relationship among barriers, demographics, and e-Learning selfefficacy.," 2004

[13] I. Fardani, I.H. Agustina, and F.A. Jauzi, "Implementing SWOT analysis in engineering education," in IOP Conference Series: Materials Science and Engineering, 2020, vol. 830, no. 3, p. 32066

[14] E. Gürel and M. Tat, "SWOT analysis: a theoretical review.," J. Int. Soc. Res., vol. 10, no. 51, 2017

[15] F. Rangkuti, Analisis SWOT teknik membedah kasus bisnis. Gramedia Pustaka Utama, 1998.

[16] R. Faslah and H.B. Santoso, "Analisis Kesiapan Implementasi ELearning Menggunakan E-Learning Readiness Model,” POSITIF J. Sist. dan Teknol. Inf., vol. 3, no. 2, pp. 113-120, 2017. 